\title{
RANCANG BANGUN TSUNAMI PODS SEBAGAI TEMPAT EVAKUASI SEMENTARA (TES) UNTUK MEWUJUDKAN WILAYAH TANGGUH BENCANA
}

\author{
Mirza Ghulam Rifqi', M. Shofi'ul Amin², Enes Ariyanto Sandi ${ }^{3}$ \\ ${ }^{1}$ Jurusan Teknik Sipil, Politeknik Negeri Banyuwangi, Banyuwangi 68461 \\ E-mail:mirza@poliwangi.ac.id \\ ${ }^{2}$ Jurusan Teknik Sipil, Politeknik Negeri Banyuwangi, Banyuwangi 68461 \\ E-mail:shofiul@poliwangi.ac.id \\ ${ }^{3}$ Jurusan Teknik Sipil, Politeknik Negeri Banyuwangi, Banyuwangi 68461 \\ E-mail:ennesariyanto.sandi@gmail.com
}

\begin{abstract}
ABSTRAK
Indonesia merupakan negara kepulauan yang berada pada pertemuan 3 lempeng besar dunia, yaitu lempeng Indo-Australia, lempeng eurasia dan lempeng Pasifik. Selain pergerakan lempeng bumi, aktivitas gunung berapi juga menjadi penyebab bencana gempa bumi. Hal-hal tersebut menjadikan sebagian wilayah Indonesia sebagai wilayah rawan gempa dan tsunami. Dalam kejadian tsunami, jatuhnya korban dikarenakan terlambat menyelamatkan diri yang disebabkan terlambatnya early warning yang diinformasikan pihak terkait dan ketersediaan infrastruktur Tempat Evakuasi Sementara (TES) yang minim. Rancang bangun dimulai dari penentuan desain dan bentuk awal tsunami pods. Rancangan bentuk awal pods adalah persegi panjang dengan akses masuk diletakkan di atap pods. Selanjutnya adalah dengan melakukan penentuan material yang digunakan sebagai rangka utama dan penutup atau dinding tsunami pods. Evaluasi kekuatan struktur dari kombinasi material dan kombinasi beban dilakukan dengan menganalisis pembebanan dan struktur serta pemodelan konstruksi tsunami pods menggunakan software bantu. Berdasarkan hasil analisis struktur, konstruksi struktur tsunami pods dimodelkan dengan menggunakan material struktur menggunakan baja WF 250.125.6.9 sebagai rangka utama dan baja UNP 100.50.5 sebagai bracing dan pelat baja corrugated SS $400 \mathrm{t} .6 \mathrm{~mm}$ untuk dinding dan atap, tebal $12 \mathrm{~mm}$ untuk deck lantai. Hasil analisis menyatakan, rangka dan pelat yang digunakan mampu menahan beban rencana dan desain pods mampu menampung 24 orang.

Kata Kunci:
\end{abstract}

Lempeng, tsunami, evakuasi, pods, baja

\section{PENDAhuluan}

Indonesia merupakan negara yang berada pada lempeng bumi yang berdekatan yaitu lempeng Indo-Australia, lempeng eurasia dan lempeng Pasifik. Hal ini menjadi salah satu penyebab sering terjadinya bencana gempa bumi. Jalur pertemuan lempeng tektonik (zona subduksi) merupakan daerah potensi gempa yang cukup tinggi. Posisi Indonesia pada lempeng dunia ditunjukkan pada Gambar 1 .

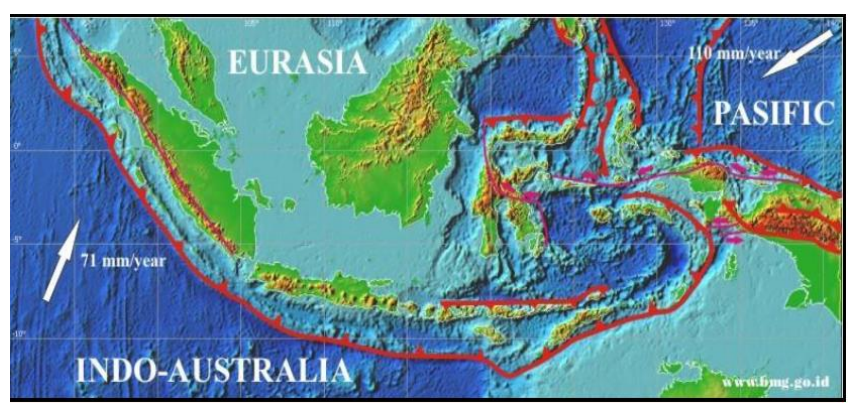

Gambar 1 Posisi Indonesia pada lempeng dunia [1]

Selain pergerakan lempeng bumi, aktivitas gunung berapi juga menjadi penyebab bencana gempa bumi. Indonesia memiliki 127 gunung aktif [4] dimana beberapa diantaranya berada di bawah laut. Hal-hal tersebut menjadikan sebagian wilayah Indonesia sebagai wilayah rawan bencana gempa dan tsunami. Tsunami sendiri mengancam kawasan pesisir
Indonesia terutama yang berhadapan dengan Samudera Hindia.

Tsunami merupakan gelombang besar yang terjadi akibat gangguan yang terjadi didasar laut [2]. Gangguan tersebut bisa terjadi akibat gempa, erupsi dasar laut, longsoran dan lain sebagainya. Tercatat beberapa tsunami di Indonesia antara lain : tsunami di Banyuwangi (1994), tsunami Aceh (2004), tsunami di Banten (2018) dan lain sebagainya. Seringnya gempa yang terjadi terutama yang terjadi di tengah laut, mengharuskan tiap daerah rawan tsunami harus siap dengan mekanisme mitigasi bencana. Kejadian gempa yang terjadi di Indonesia ditunjukkan pada Gambar 2.

Dalam kejadian tsunami, jatuhnya korban dikarenakan terlambat menyelamatkan diri. Hal ini disebabkan terlambatnya early warning yang diinformasikan pihak terkait dan ketersediaan infrastruktur tempat evakuasi sementara yang minim. Kecepatan masyarakat dalam menyelamatkan diri tidak sepadan dengan kecepatan gelombang tsunami. Kecepatan tsunami dilaut dalam berkisar antara 500-1000 km/jam dengan ketinggian gelombang sekitar $1 \mathrm{~m}$. ketika mendekati pantai, kecepatan tsunami menurun hingga $30 \mathrm{~km} / \mathrm{jam}$ dengan ketinggian yang semakin bertambah hingga puluhan meter [2]. 


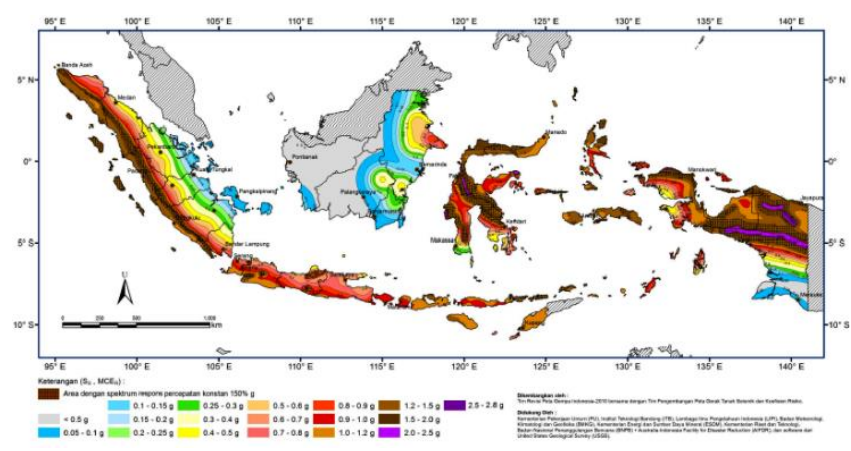

Gambar 2 Peta Gempa Indonesia [5]

Permasalahan yang terjadi adalah, mayoritas daerah rawan bencana tsunami belum siap dalam menghadapi bencana tsunami. Hal ini disebabkan oleh belum siapnya daerah rawan bencana dalam menghadapi bencana tsunami baik dalam hal infrastruktur evakuasi maupun rencana tanggap darurat. Untuk itu, diperlukan penelitian tentang Tempat Evakuasi Sementara (TES) untuk mewujudkan daerah tangguh bencana.

Penelitian ini dilakukan dengan tujuan untuk mewujudkan daerah tangguh bencana, yaitu dengan menghadirkan solusi alternatif dalam desain bangunan evakuasi sementara. Penelitian ini difokuskan pada desain arsitektur dan desain struktur atas bangunan evakuasi sementara. Selanjutnya, hasil penelitian akan digunakan untuk pengembangan infrastruktur mitigasi bencana.

Penelitian difokuskan pada struktur atas shelter. Perhitungan struktur bawah dilakukan pada penelitian selanjutnya. Lokasi penelitian dilakukan di kawasan pesisir Kabupaten Banyuwangi dengan kondisi tanah lunak.

\section{STUDI PUSTAKA}

\section{Tsunami}

Setiap tempat memiliki waktu evakuasi yang berbeda tergantung pada kuatnya gempa bumi yang terjadi dan lokasi gempa bumi. Sumber terjadinya tsunami yang jauh, memberikan waktu evakuasi yang cukup. Sebaliknya sumber terjadinya tsunami yang dekat tidak memberikan waktu evakuasi yang cukup. Dalam hal ini penyusunan rencana mitigasi dan rencana respons tanggap darurat membutuhkan Tempat Evakuasi Sementara (TES). Keberadaan early warning system sangat dibutuhkan masyarakat sebagai tanda peringatan perlunya segera evakuasi. Hal ini diperlukan mengingat tidak semua fenomena tsunami mempunyai tanda-tanda alam yang sama. Demikian pula untuk fenomena tele-tsunami yaitu tsunami yang terjadi dengan sumber tsunami yang berada di sisi lain samudera seperti Samudera Hindia dan/atau Samudera Pasifik, keberadaan sistem peringatan dini sangat dibutuhkan untuk peringatan tanda evakuasi.

\section{Tempat Evakuasi Sementara (TES)}

Strategi penyelamatan sebelum gelombang tsunami tiba adalah mengevakuasi manusia dari zona bencana baik secara horizontal ataupun vertikal. Di beberapa daerah, evakuasi vertikal kemungkinan merupakan satu-satunya cara evakuasi dari bahaya tsunami setempat dengan waktu peringatan yang singkat. Proses evakuasi merupakan cara tanggap darurat dan persiapan darurat, sehingga pertimbangan mitigasi yang utama adalah menentukan lokasi, mendesain, dan membangun bangunan yang dapat menahan gaya-gaya tsunami yang diperkirakan dan guncangan tanah akibat gempa.

Menurut [3] kemampuan rata-rata orang sehat dapat berjalan dengan kecepatan $6,44 \mathrm{~km}$ per jam atau setara dengan $107 \mathrm{~m}$ per menit. Untuk memfasilitasi lokasi evakuasi, diperlukan TES yang dapat dijangkau oleh masyarakat. Referensi [3] sudah merumuskan mengenai jarak maksimum TES berdasarkan waktu peringatan. Rumusan tersebut dijabarkan pada Tabel 1

Tabel 1 Jarak maksimum TES berdasarkan waktu peringatan [3]

\begin{tabular}{c|c|c|c}
\hline $\begin{array}{c}\text { Waktu } \\
\text { Wedatangan/ } \\
\begin{array}{c}\text { Tsunami } \\
\text { (ETA) }\end{array}\end{array}$ & $\begin{array}{c}\text { Kecepatan } \\
\text { Orang } \\
\text { Berjalan } \\
\text { (Lemah) }\end{array}$ & $\begin{array}{c}\text { Jarak } \\
\text { Perubahan } \\
\text { Menuju } \\
\text { TES }\end{array}$ & $\begin{array}{c}\text { Jarak } \\
\text { Maksimum } \\
\text { antara 2 } \\
\text { Lokasi TES }\end{array}$ \\
\hline $\mathbf{2 ~ j a m}$ & $3,22 \mathrm{~km} / \mathrm{jam}$ & $6,44 \mathrm{~km}$ & $12,87 \mathrm{~km}$ \\
\hline $\mathbf{3 0}$ menit & $3,22 \mathrm{~km} /$ jam & $1,61 \mathrm{~km}$ & $3,22 \mathrm{~km}$ \\
\hline $\mathbf{1 5}$ menit & $3,22 \mathrm{~km} / \mathrm{jam}$ & $804,5 \mathrm{~km}$ & $1,61 \mathrm{~km}$ \\
\hline
\end{tabular}

Jarak TES yang sesuai untuk wilayah Indonesia adalah kurang dari $1 \mathrm{~km}$ atau kurang lebih $699 \mathrm{~m}$ dari garis pantai. Dengan jarak ini, waktu yang dibutuhkan untuk mencapai TES kurang lebih 12,15 menit [12]. Untuk mencapai TES dengan kecepatan yang sudah diprediksikan, maka fasilitas pendukung seperti jalan dan jalur evakuasi dari rumah menuju TES harus disiapkan dengan kondisi baik [13].

Kebutuhan TES di Indonesia sebagai tempat evakuasi masih sangat kurang. Kabupaten Padang sendiri memiliki 13 TES dan jumlah tersebut masih sangat kurang untuk mencakup luasan wilayah Kabupaten Padang [8]. Untuk beberapa daerah dengan potensi bahaya khusus di daerah tersebut, diperkenalkan tempat evakuasi untuk tiap orang, atau lebih dikenal lubang evakuasi [15].

\section{Penentuan Tata Ruang}

Dengan mempertimbangkan efektivitas penggunaan ruang dan kenyamanan pengguna pods, maka diperlukan dasar perhitungan kebutuhan ruangan untuk tiap orang beserta space yang dibutuhkan oleh masing-masing orang.

Standar ukuran manusia dan kebutuhan ruang untuk manusia dengan posisi duduk, menggunakan standar universal dan ukuran manusia serta kebutuhan ruang manusia [9] sebagaimana ditunjukkan pada Gambar 3. 
Dengan mempertimbangkan efektivitas penggunaan ruang dan kenyamanan pengungsi di tempat evakuasi tsunami maka dipilih standar kebutuhan ruang dari "Architecs' Data" seperti pada [9] dimana pengungsi diasumsikan duduk di atas kursi selama menunggu waktu kritis gelombang tsunami mereda.

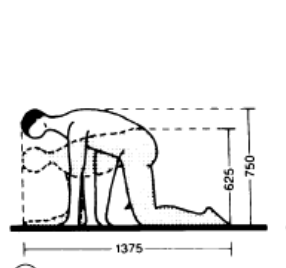

(1)
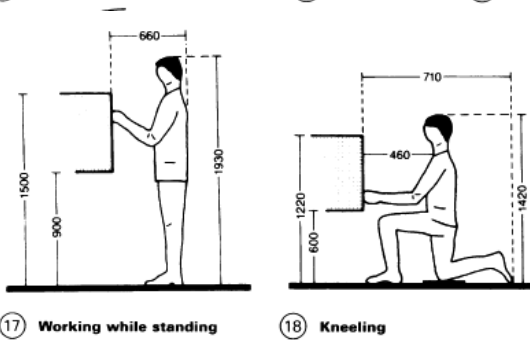

(18) Kneeling

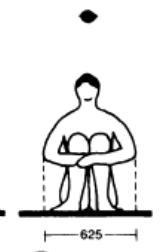

(3)

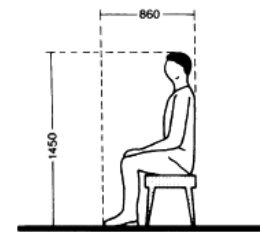

(19) Sitting
Gambar 3 Kebutuhan ruang manusia dengan posisi duduk di kursi [9]

\section{Perhitungan Struktur}

Dalam hal ini, pembebanan struktur baja didasarkan pada [6] tentang Spesifikasi untuk Bangunan Gedung Baja Struktural.. Analisis pembebanan dan kombinasi pembebanan dilakukan dengan bantuan software bantu.

\section{Beban Mati (Dead Load)}

Merupakan beban yang diakibatkan oleh berat konstruksi permanen, termasuk dinding, lantai, atap, plafon, partisi tetap, tangga, dan peralatan layan tetap [2]. Termasuk di dalamnya adalah berat kolom, balok, pelat dan komponenkomponen di dalam bangunan yang membebani struktur bangunan. Beban mati pada struktur bangunan tsunami pods adalah rangka baja.

Tabel 2 Data berat material rangka baja

\begin{tabular}{l|c|c}
\hline \multicolumn{1}{c|}{ Beban } & Profil & $\begin{array}{l}\text { Berat } \\
\text { Kg/m }\end{array}$ \\
\hline Kolom & WF 250.125.6.9 & $29,60 \mathrm{~kg}$ \\
Balok Memanjang & WF 250.125.6.9 & $29,60 \mathrm{~kg}$ \\
Balok Melintang & WF 250.125.6.9 & $29,60 \mathrm{~kg}$ \\
Balok Pembagi & UNP 100.50.5 & $9,37 \mathrm{~kg}$ \\
\hline
\end{tabular}

Tabel 3 Data berat material pelat penutup

\begin{tabular}{l|l|l}
\hline \multicolumn{1}{c|}{ Beban } & \multicolumn{1}{c|}{ Profil } & $\begin{array}{c}\text { Berat } \\
\text { Kg/m }\end{array}$ \\
\hline Pelat CSP dinding & SS 400 t. $6 \mathrm{~mm}$ & $14,60 \mathrm{~kg}$ \\
Pelat CSP atap & SS 400 t. $6 \mathrm{~mm}$ & $14,60 \mathrm{~kg}$ \\
Pelat CSP lantai & SS 400 t. $12 \mathrm{~mm}$ & $14,60 \mathrm{~kg}$ \\
Pelat datar lantai & SS 400 t. $12 \mathrm{~mm}$ & $14,60 \mathrm{~kg}$ \\
\hline
\end{tabular}

Beban mati tsunami pods terdiri dari beban mati kolom, balok, bracing dan pelat baja penutup tsunami pods. Beban struktur utama rangka baja yang digunakan disajikan pada Tabel 2 dan beban pelat penutup tsunami pods ditunjukkan pada Tabel 3 .

\section{Beban Hidup (Live Load)}

Merupakan beban yang ditimbulkan oleh penggunaan gedung, termasuk kejut, tetapi tidak termasuk beban lingkungan seperti angin, hujan, dan lain-lain [6]. Di dalamnya termasuk manusia yang beraktivitas pada bangunan tersebut, barang-barang yang dapat dipindahpindah dan membebani lantai dan komponen struktur bangunan.

\section{Beban Gempa (Earthquake Load)}

Merupakan beban yang ditimbulkan oleh gempa [6]. Analisis beban gempa bisa dilakukan menggunakan analisis gempa dinamik dan analisis gempa statik ekuivalen. Beban gempa dan mekanisme perhitungan struktur terhadap beban gempa menggunakan referensi [5].

\section{Beban Tsunami (Tsunami Load)}

Beban tsunami merupakan beban yang terjadi akibat pergerakan tsunami, yang diakibatkan oleh gaya hidrostatis, gaya apung, gaya hidrodinamik, gaya impulsif, gaya tumbukan debris atau hanyutan puing, gaya tahanan debris atau hanyutan puing, gaya uplift dan beban gravitasi tambahan oleh genangan air di atap atau lantai atas [3]. Dalam menghitung beban-beban tsunami

Gaya hidrostatis dan gaya apung harus dihitung ketika lantai dasar bangunan cukup kedap air dan cukup terisolasi dari masuknya air [3]. Distribusi gaya hidrostatis dan lokasi resultan ditunjukkan pada Gambar 4. Gaya hidrostatis dan gaya apung dapat dihitung menggunakan persamaan ( 1 ).

$$
F_{h}=p_{c} \cdot A_{w}=\frac{1}{2} \rho_{s} \cdot g \cdot b \cdot h_{\max }^{2}
$$

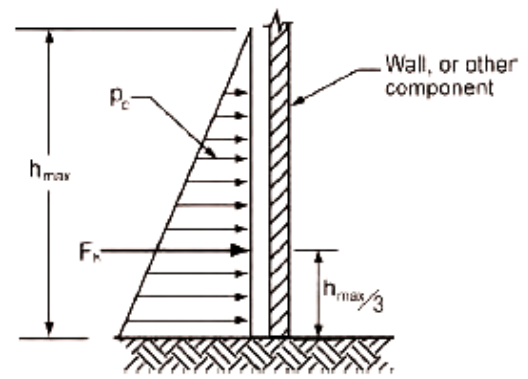

Gambar 4 Distribusi gaya hidrostatis dan lokasi resultan [3]

Gaya apung akan bekerja secara vertikal ke atas. Gaya apung sebanding dengan berat air yang memasuki bangunan [4]. Untuk struktur yang kedap air, gaya apung total dapat dihitung menggunakan persamaan ( 2 ).

$$
F_{b}=\rho_{s} \cdot g \cdot V
$$


Ketika air mengalir di sekitar struktur bangunan, hal tersebut mengakibatkan tiap komponen struktur akan mengalami gaya hidrodinamik [3]. Distribusi gaya hidrodinamik dan lokasi resultannya ditunjukkan pada Gambar 5. Gaya hidrodinamik dapat dihitung menggunakan persamaan ( 3 )

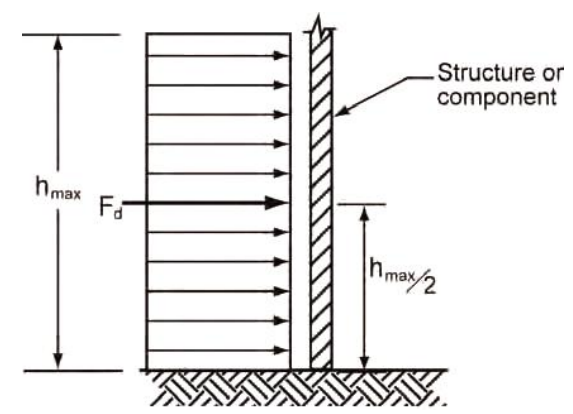

Gambar 5 Distribusi gaya hidrodinamik dan lokasi resultan [3]

$$
F_{d}=\frac{1}{2} \rho_{s} \cdot C_{d} \cdot B \cdot\left(h u^{2}\right)_{\max }
$$

Gaya impulsif terjadi pada struktur yang pertama kali dihantam gelombang. Hampir di setiap struktur bangunan mengalami hantaman gelombang pada saat gelombang pertama datang. Menurut data uji laboratorium, kekuatan impulsif maksimum kurang lebih 1,5 kali dari gaya hidrodinamik [3]. Untuk mengetahui kekuatan gaya impulsif, bisa menggunakan persamaan (4).

$$
F_{s}=1,5 \cdot F_{d}
$$

Dampak dari gaya hempasan gelombang yang membawa serpihan atau puing-puing (debris) atau bongkahan material (kayu, perahu, kapal, material, mobil dll.) dapat mengakibatkan kerusakan yang dominan pada bangunan [3]. Gaya pukulan debris dapat dihitung menggunakan persamaan ( 5 ).

$$
F_{i}=C_{m} \cdot u_{\max } \cdot \sqrt{k \cdot m}
$$

\section{Kombinasi Pembebanan}

Dalam perhitungan pembebanan, kombinasi pembebanan mengikuti standar yang dijelaskan pada [3]. Kombinasi pembebanan untuk tsunami pods adalah :

Kombinasi $1: 1,2 D+1,0 T_{s}+1,0 L_{R E F}+0,25 L$

Kombinasi $2: 0,9 D+1,0 T_{s}$

Dimana $D$ adalah beban mati, $T_{s}$ adalah beban tsunami, $L_{R E F F}$ adalah beban pelaksanaan dan $L$ adalah beban hidup selain beban pelaksanaan [3].

\section{METODOLOGI}

\section{Penentuan Desain Awal Tsunami Pods}

Penelitian ini dimulai dari penyusunan pradesain, desain konstruksi Desain awal bangunan tsunami pods ditentukan, yaitu dengan sistem pod berbentuk persegi panjang.
Dimensi ditentukan berdasarkan kebutuhan ruang sebagaimana dijelaskan pada [9].

\section{Analisis Struktur dan Pembebanan}

Setelah dilakukan penentuan bentuk dan desain tsunami pods, selanjutnya dilakukan analisis pembebanan dan struktur terhadap desain secara 3D menggunakan bantuan software. Analisis dilakukan untuk material penyusun tsunami pods, beban rencana dan konstruksi bangunan. Beban rencana disesuaikan dengan pedoman seperti pada [3].

\section{Pemodelan dan Desain Konstruksi Tsunami Pods}

Hasil analisis terhadap desain tsunami pods, dijadikan dasar pemodelan dan desain akhir konstruksi struktur tsunami pods. Material yang sudah dianalisis ditetapkan sebagai material struktur untuk tsunami pods.

\section{Analisis dan Kesimpulan}

Hasil analisis material penyusun tsunami pods dan hasil gambar perencanaan tsunami pods disusun dan dianalisis serta dlakukan pembahasan. Hasil dari analisis dan pembahasan menjadi perimbangan dan kesimpulan mengenai konsep tsunami pods.

\section{ANALISIS DAN PEMBAHASAN}

\section{Penentuan Desain Awal Tsunami Pods}

Penentuan desain awal tsunami pods menggunakan bentuk persegi panjang dengan $11 \mathrm{~m}$ x $3.025 \mathrm{~m}$. Material konstruksi yang digunakan adalah baja WF 250.125.6.9 sebagai rangka utama dan baja UNP 100.50 .5 sebagai bracing serta pelat corrugated SS 400 sebagai penutup tsunami pods. Kebutuhan ruang duduk tiap orang dengan menggunakan kursi adalah $0,54 \mathrm{~m}^{2}$ yaitu $0,86 \mathrm{~m} \times 0,625 \mathrm{~m}$. Tata ruang utama tsunami pods terbagi dalam 2 (dua) ruang utama, yaitu ruang penyimpanan dan ruang berlindung. Dimensi ruang penyimpanan adalah $3.025 \mathrm{~m} \mathrm{x} 2.063 \mathrm{~m}$ sedangkan dimensi ruang berlindung adalah $8,938 \mathrm{~m} \mathrm{x}$ $3.025 \mathrm{~m}$. Denah tsunami pods ditunjukkan pada Gambar 6 .

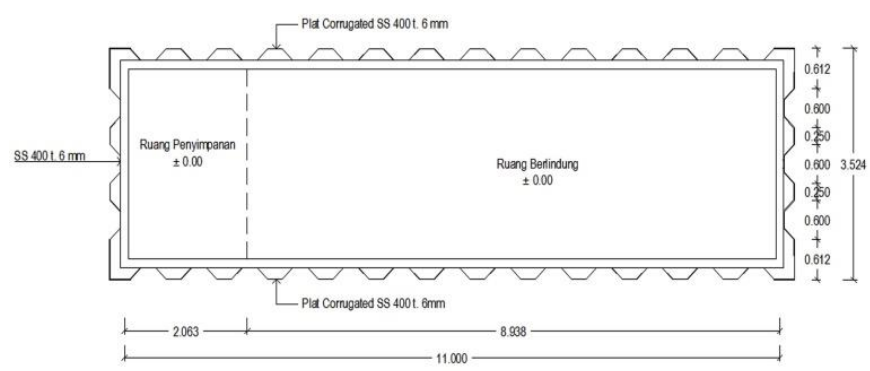

Gambar 6 Denah tsunami pods

\section{Analisis Struktur dan Pembebanan}

Material yang digunakan pada desain tsunami pods Perencanaan rangka utama menggunakan baja WF 250.125.6.9 sebagai rangka utama dan baja UNP 100.50.5 
sebagai bracing serta pelat corrugated SS 400 sebagai penutup tsunami pods. Mutu material yang digunakan ditunjukkan pada Tabel 4. Hasil analisis struktur dituangkan ke dalam gambar rencana struktur tsunami pods, seperti yang ditunjukkan pada Gambar 7 .

\begin{tabular}{l|ll|ll}
\multicolumn{5}{c}{ Tabel 4 Mutu material } \\
\hline \multicolumn{1}{c|}{ Material } & \multicolumn{2}{c}{$\boldsymbol{f}_{\boldsymbol{y}}$} & \multicolumn{2}{c}{$\boldsymbol{f}_{\boldsymbol{u}}$} \\
\hline WF 250.125.6.9 & 2400 & $\mathrm{~kg} / \mathrm{cm}^{2}$ & 3700 & $\mathrm{~kg} / \mathrm{cm}^{2}$ \\
UNP 100.50.5 & 2400 & $\mathrm{~kg} / \mathrm{cm}^{2}$ & 3700 & $\mathrm{~kg} / \mathrm{cm}^{2}$ \\
SS 400 & 2400 & $\mathrm{~kg} / \mathrm{cm}^{2}$ & 3700 & $\mathrm{~kg} / \mathrm{cm}^{2}$ \\
\hline
\end{tabular}

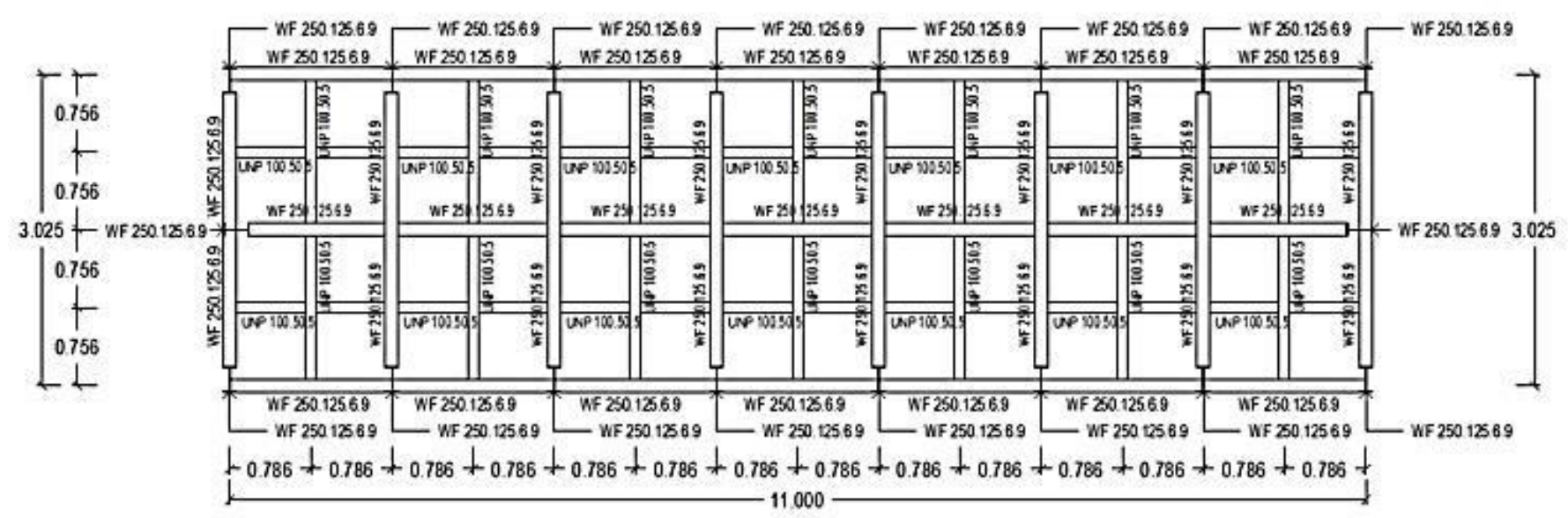

Gambar 7 Rencana struktur tsunami pods

Berat konstruksi rangka utama WF 250.125.6.9 adalah $3.065,080 \mathrm{~kg}$ dan bracing UNP 100.50 .5 adalah 371,570 $\mathrm{kg}$. Berat pelat penutup rangka CSP $\mathrm{t}=6 \mathrm{~mm}$ adalah $1.401,235 \mathrm{~kg}$, CSP $\mathrm{t}=12 \mathrm{~mm}$ adalah $485,815 \mathrm{~kg}$, pelat datar $\mathrm{t}=6 \mathrm{~mm}$ adalah $485,815 \mathrm{~kg}$. Berat total konstruksi baja tsunami pods adalah $6.408,461 \mathrm{~kg}$.

\section{Beban tsunami}

Beban tsunami yang diperhitungkan dalam desain struktur tsunami pods adalah gaya hidrodinamik, gaya impulsif, gaya tahanan terhadap tumbukan puing atau hanyutan puing dan gaya tumbukan puing. Berdasarkan hasil perhitungan, didapatkan data beban tsunami, antara lain :

$\begin{array}{llr}\text { Gaya hidrodinamik }\left(F_{h}\right) & = & 725,528 \mathrm{kN} / \mathrm{m} \\ \text { Gaya impuls }\left(F_{s}\right) & = & 8,800 \mathrm{kN} / \mathrm{m} \\ \text { Gaya tumbukan puing }\left(\mathrm{F}_{\mathrm{i}}\right) & = & 5,867 \mathrm{kN} / \mathrm{m} \\ \text { Gaya Uplift }\left(\mathrm{F}_{\mathrm{b}}\right) & = & 39,171 \mathrm{kN} / \mathrm{m}\end{array}$

\section{Beban Gempa}

Berdasarkan kombinasi pembebanan yang dijelaskan pada referensi [3], komponen beban gempa tidak terdapat dalam kombinasi pembebanan. Komponen pembebanan yang terdapat pada kombinasi pembebanan adalah beban mati (D), beban tsunami $\left(\mathrm{T}_{\mathrm{s}}\right)$, beban pelaksanaan ( $\mathrm{L}_{\mathrm{REFF}}$ ) dan beban hidup selain beban pelaksanaan (L). Meskipun demikian, perlu dilakukan pemeriksaan kekuatan terhadap beban gempa.

Beban gempa yang dipakai yaitu menggunakan beban gempa respons spectrum yang mengacu referensi dan mempertimbangkan dengan hasil dari aplikasi Pusat Penelitian dan Pengembangan Perumahan dan Pemukiman Kementerian PUPR. Setelah dikroscek dengan peta gempa pada aplikasi Pusat Penelitian dan Pengembangan Perumahan dan Pemukiman Kementerian PUPR hasilnya sama. Sehingga nilai tersebut digunakan dalam menentukan grafik respons spektrumnya. Nilai Respons Spektrum Desain disajikan pada Tabel 5 dan grafik respons spektrum ditunjukkan pada Gambar 8.

Tabel 5 Perhitungan Respons Spektrum Desain

\begin{tabular}{lll}
\hline $\begin{array}{c}\text { Simbol Waktu } \\
\text { Getar }\end{array}$ & \multicolumn{1}{c}{$\begin{array}{c}\text { Waktu } \\
\text { Getar }\end{array}$} & \multicolumn{1}{c}{$(\boldsymbol{T})$}
\end{tabular}




\begin{tabular}{lll}
\hline $\begin{array}{c}\text { Simbol Waktu } \\
\text { Getar } \\
(\boldsymbol{T})\end{array}$ & $\begin{array}{c}\text { Waktu } \\
\text { Getar } \\
(\boldsymbol{T})\end{array}$ & $\begin{array}{c}\text { Percepatan } \\
\text { Respons Spektra } \\
(\text { Sa })\end{array}$ \\
\hline $\mathrm{T}_{\mathrm{s}}+2,5$ & 3.428 & 0.165403 \\
\hline $\mathrm{T}_{\mathrm{s}}+2,6$ & 3.528 & 0.160714 \\
\hline $\mathrm{T}_{\mathrm{s}}+2,7$ & 3.628 & 0.156284 \\
\hline $\mathrm{T}_{\mathrm{S}}+2,8$ & 3.728 & 0.152092 \\
\hline $\mathrm{T}_{\mathrm{s}}+2,9$ & 3.828 & 0.148119 \\
\hline $\mathrm{T}_{\mathrm{S}}+3,0$ & 3.928 & 0.144348 \\
\hline 3.1 & 4 & 0.14175 \\
\hline
\end{tabular}

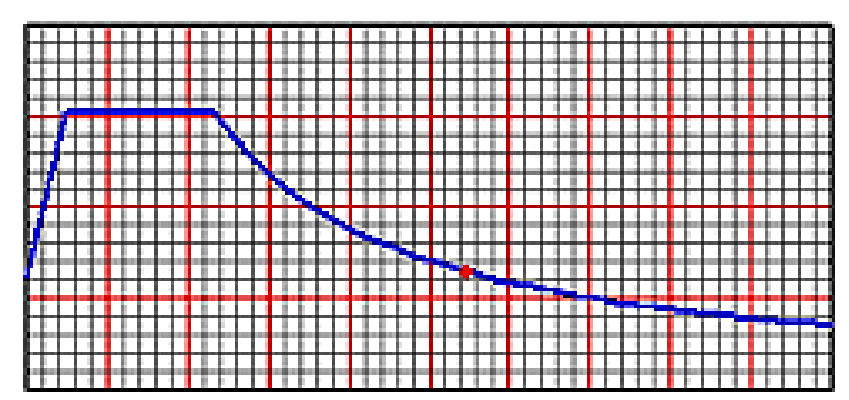

Gambar 8 Respons spectrum Desain

Hasil simpangan yang terjadi akibat gempa arah $\mathrm{X}$ menunjukkan nilai mendekati 0 . Hal tersebut bernilai sangat kecil sekali, sehingga dipastikan akibat gempa konstruksi tersebut masih aman. Hal ini ditunjukkan pada Gambar 9.

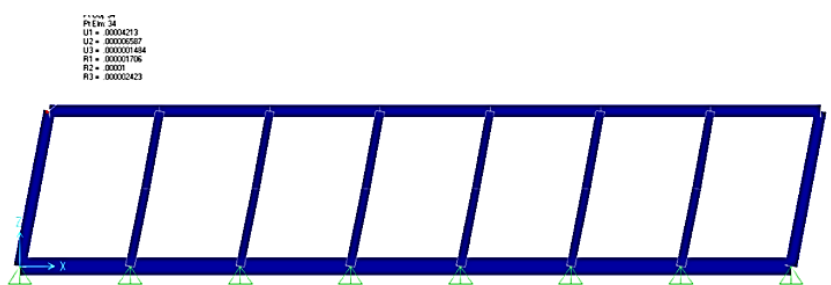

Gambar 9 Hasil Simpangan yang terjadi akibat gempa arah $\mathrm{X}$

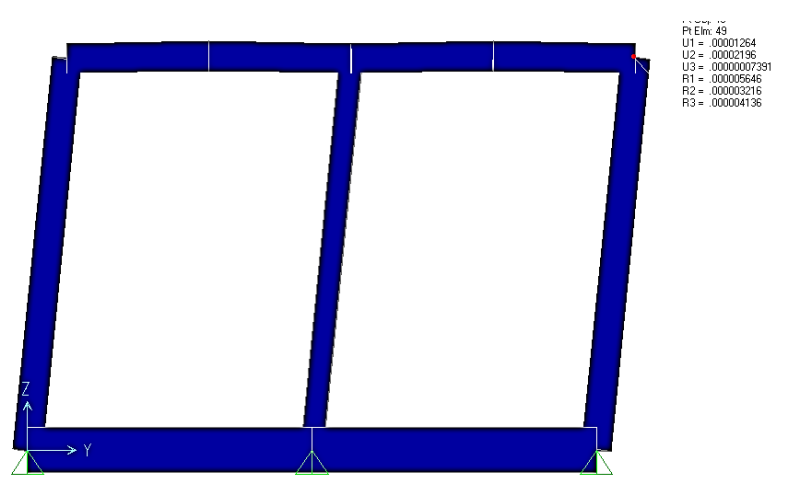

Gambar 10 Hasil Simpangan yang terjadi akibat gempa arah Y

Hasil simpangan yang terjadi akibat gempa arah $\mathrm{Y}$ menunjukkan nilai mendekati 0 . Hal tersebut bernilai sangat kecil sekali, sehingga dipastikan akibat gempa konstruksi tersebut masih aman. Hal ini ditunjukkan pada Gambar 10.

\section{Analisis pelat CSP}

Analisis pelat CSP dan pelat datar digunakan untuk mengetahui karakteristik material pelat yang digunakan. Ilustrasi analisis CSP 6 mm ditunjukkan pada Gambar 11 . Dari analisis perhitungan, diperoleh :

Nilai $\mathrm{a}=17,5 \mathrm{~cm}, \mathrm{~b}=17,5 \mathrm{~cm}$

Luas penampang 1 dan 5 adalah $12 \mathrm{~cm}^{2}$, sedangkan luas penampang 2 dan 3 dan 4 adalah $15 \mathrm{~cm}^{2}$. Perhitungan titik berat terhadap $\mathrm{x}$ diperoleh nilai $10 \mathrm{~cm}$ dan perhitungan titik berat terhadap y diperoleh nilai $50 \mathrm{~cm}$.

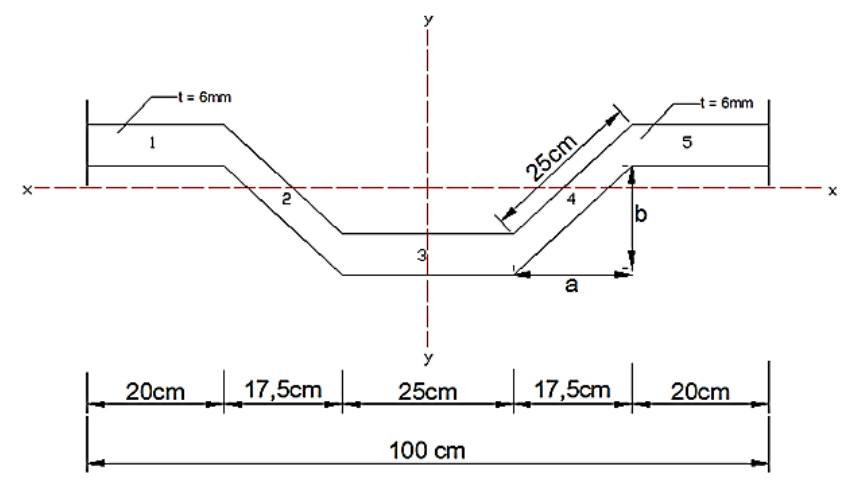

Gambar 11 Analisis CSP 6 mm pelat dinding

Perhitungan momen inersia untuk penampang 1 dan 5 adalah :

Ix $=0,36 \mathrm{~cm}^{4}$, Iy $=400 \mathrm{~cm}^{4}$

Momen inersia untuk penampang 2 dan 4 adalah :

Ix $=0,45 \mathrm{~cm}^{4}$, Iy $=781,25 \mathrm{~cm}^{4}$

\section{Analisis pelat datar}

Perhitungan titik berat terhadap $\mathrm{x}$ diperoleh nilai $0,3 \mathrm{~cm}$ dan perhitungan titik berat terhadap y diperoleh nilai 50 $\mathrm{cm}$. Perhitungan momen inersia adalah :

Ix $=1,8 \mathrm{~cm}^{4}$, Iy $=50000 \mathrm{~cm}^{4}$

Ilustrasi analisis pelat datar $6 \mathrm{~mm}$ ditunjukkan pada Gambar 12.

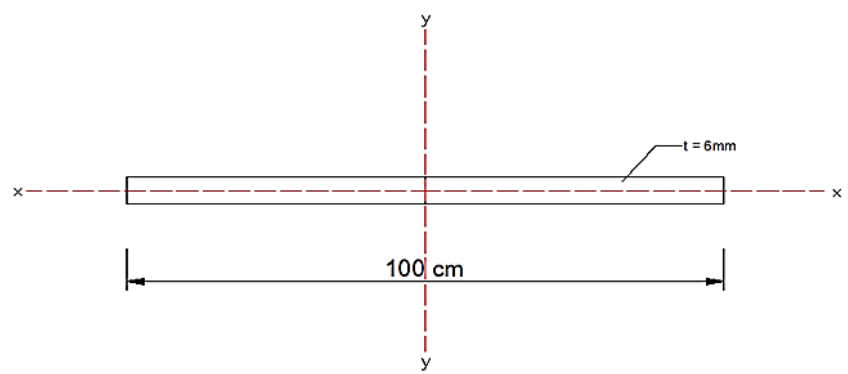

Gambar 12 Analisis pelat datar $6 \mathrm{~mm}$ pelat dinding

Dapat disimpulkan bahwa untuk mengetahui modulus penampang dengan mengambil alternatif paling menentukan pada CSP :

- modulus penampang (pelat biasa $\mathrm{t}=6 \mathrm{~mm}$ )

$$
\mathrm{Zx} 1=\frac{I x}{y} \quad=\frac{1,8}{0,3}=6 \mathrm{~cm}^{3}
$$


- modulus penampang $(\mathrm{CSP} t=6 \mathrm{~mm})$

$$
\mathrm{Zx} 1=\frac{I x}{y} \quad=\frac{1,8}{0,3}=6 \mathrm{~cm}^{3}
$$

Nilai perbandingan $=\frac{154,51}{6}=25,75 \mathrm{kali}$

Dalam permodelan perhitungan "kontrol desain" untuk mengetahui tegangan-tegangan maksimum pada pelat/shell digunakan tebal pelat biasa pada dinding :

$\frac{1}{10} \times 6 \times 25,75=15,45 \mathrm{~mm}=15 \mathrm{~mm}$

Selanjutnya, kontrol desain dilakukan dengan menggunakan aplikasi program bantu komputer struktur.

\section{Analisis dan Pemodelan 3D Tsunami Pods}

Hasil analisis disimulasikan secara 3D menggunakan software bantu komputer. Simulasi dilakukan untuk mengetahui tegangan-tegangan yang terjadi pada rencana tsunami pods. Komponen struktur yang mengalami tegangan dan beban luar seperti beban tsunami, beban/gaya debris dsb adalah pelat pembungkus shelter. Berdasarkan hasil pemodelan, menunjukkan bahwa tegangan maksimum terjadi pada area bawah tsunami pods. Sebagaimana rumusan pada perhitungan beban tsunami, dimana 1/3 tinggi dinding menerima beban tumbukan puing (debris). Permodelan tegangan tsunami pods ditunjukkan pada Gambar 13.

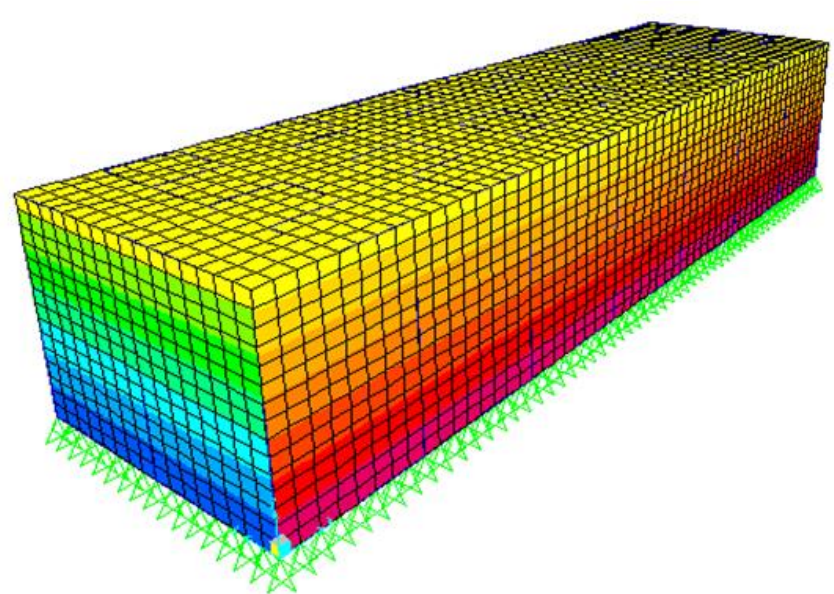

Gambar 13 Permodelan tegangan tsunami pods

Tegangan maksimum yang terjadi pada pelat dinding tsunami pods sebesar $1.814,88 \mathrm{~kg} / \mathrm{cm}^{2}$. Nilai tegangan yang terjadi pada pelat dinding tsunami pods masih di bawah nilai tegangan maksimum material, yaitu $3.700 \mathrm{~kg} / \mathrm{cm}^{2}$. Ilustrasi tegangan yang terjadi pada pelat dinding tsunami pods ditunjukkan pada Gambar 14.

Gambar 15 menunjukkan nilai tegangan maksimum yang terjadi pada pelat atap tsunami pods yaitu sebesar 3.179,41 $\mathrm{kg} / \mathrm{cm}^{2}$. Nilai ini masih berada di bawah nilai tegangan maksimum material pelat atap, yaitu sebesar $3.700 \mathrm{~kg} / \mathrm{cm}^{2}$. Beban yang diterima oleh atap adalah beban mati dan gravitasi tambahan akibat terjadinya penambahan air di atap tsunami pods.

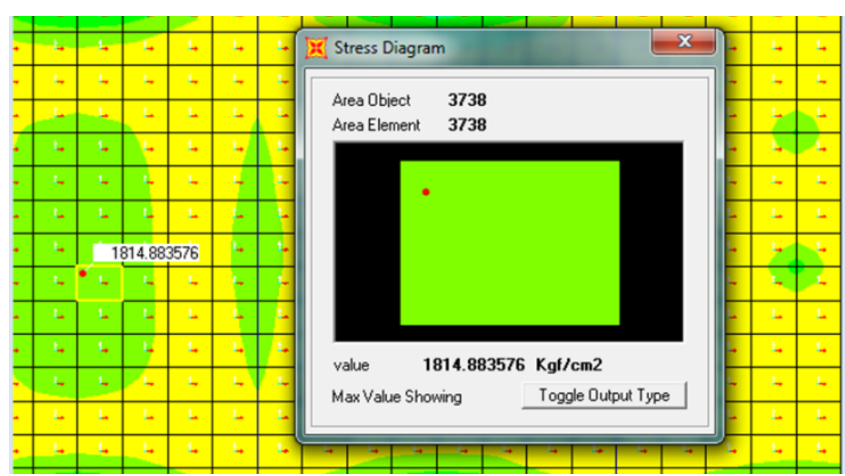

Gambar 14 Tegangan maksimum wall plate pada tsunami pods

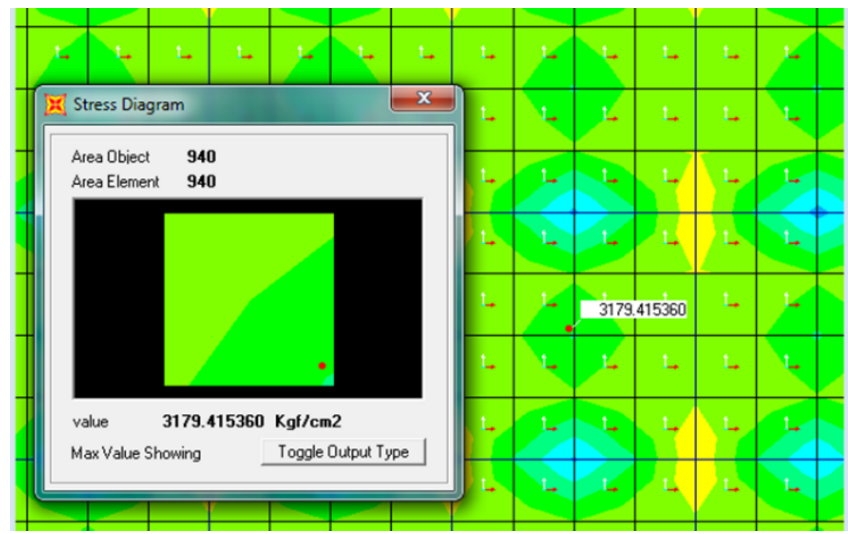

Gambar 15 Tegangan maksimum top plate pada tsunami pods

Bottom plate merupakan penutup bawah tsunami pods atau lantai dari tsunami pods. Beban yang diterima adalah beban hidup penumpang atau penghuni tsunami pods. Tegangan maksimum yang terjadi pada bagian ini sebesar 3.354,39 $\mathrm{kg} / \mathrm{cm}^{2}$. Nilai tersebut masih berada di bawah nilai tegangan material penutup dasar tsunami pods yaitu $3.700 \mathrm{~kg} / \mathrm{cm}^{2}$. Ilustrasi tegangan maksimum pada bottom plate ditunjukkan pada Gambar 16.

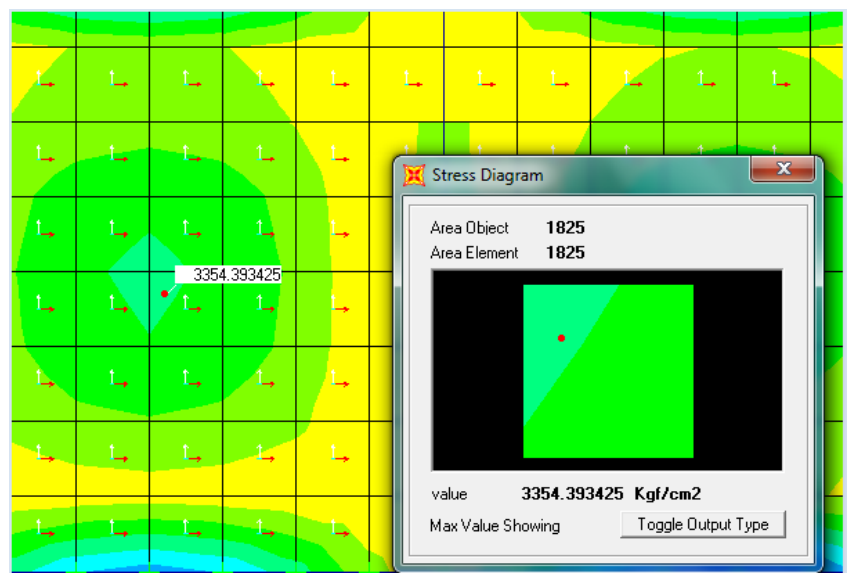

Gambar 16 Tegangan maksimum bottom plate pada tsunami pods

Berdasarkan hasil analisis dan pemodelan 3D terhadap tsunami pods, dapat disimpulkan bahwa material yang digunakan pada rencana awal desain tsunami pods aman digunakan. 


\section{Desain Konstruksi Tsunami Pods}

Desain tsunami pods menggunakan desain persegi panjang. Dimensi exterior pods panjang $11.00 \mathrm{~m}$ lebar $3.025 \mathrm{~m}$ dan tinggi $2.58 \mathrm{~m}$. Dimensi interior panjang $10.63 \mathrm{~m}$, lebar 2.65 $\mathrm{m}$ dan tinggi $2.08 \mathrm{~m}$ Tsunami pods melayani 24 orang dengan dimensi tiap kursi $0.625 \mathrm{~m}$ x $0.86 \mathrm{~m}$ dengan space sirkulasi $0.936 \mathrm{~m}$. pembagian ruang tsunami pods ditunjukkan pada Gambar 17.

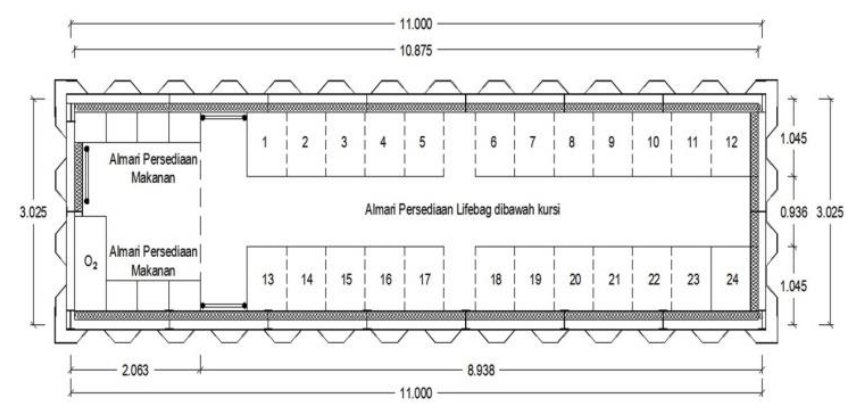

Gambar 17 Pembagian ruang dan komponen tsunami pods

Ruang penyimpanan menampung keperluan pendukung kehidupan, seperti makanan, cadangan oksigen dan obatobatan standar. Terdapat 3 (tiga) akses masuk ke dalam tsunami pods, yaitu 2 (dua) akses masuk penghuni dan 1 (satu) akses masuk maintenance. Ilustrasi kondisi tsunami pods ditunjukkan pada Gambar 18.

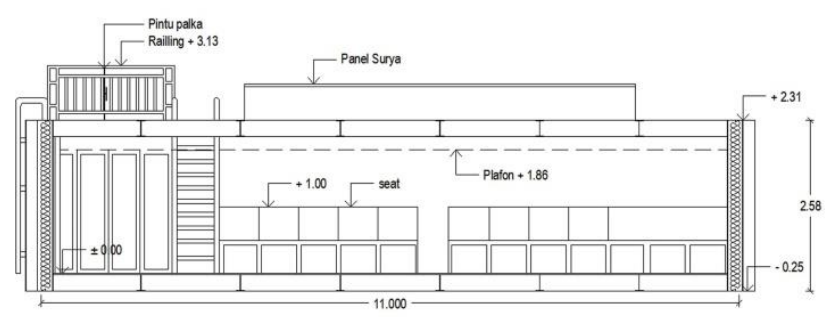

Gambar 18 Potongan memanjang tsunami pods

Dalam mendukung keselamatan tsunami pods, exterior tsunami pods dilengkapi dengan lampu obstruction yang memberi informasi mengenai posisi dan kondisi penghuni tsunami pods. Instruksi dan panduan disampaikan melalui speaker yang terdapat disisi luar tsunami pods. Suplai energi listrik diperoleh dari panel tenaga surya yang terdapat diatas tsunami pods. Input energi listrik yang diperoleh akan disimpan dalam baterai yang ada di dalam tsunami pods. Pengaman atap tsunami pods dilengkapi dengan railing untuk melindungi operator pada saat proses maintenance. Ilustrasi kondisi exterior ditunjukkan pada Gambar 19.

Energi listrik diperoleh dari panel surya pada atap dan energi cadangan listrik disimpan pada baterai yang tersimpan di bawah dek lantai. Tiap kursi dilengkapi dengan sabuk pengaman untuk menghindari cedera pada saat kemungkinan tsunami pods terguling. Di bawah kursi dilengkapi dengan jaket pelampung dan life bag yang harus dikenakan pada saat dilakukan perpindahan atau evakuasi lanjutan. Di atas kursi terdapat masker oksigen yang wajib dikenakan jika kondisi oksigen di dalam kabin terjadi penurunan. Ilustrasi kondisi kabin tsunami pods ditunjukkan pada Gambar 20 dan Gambar 21.

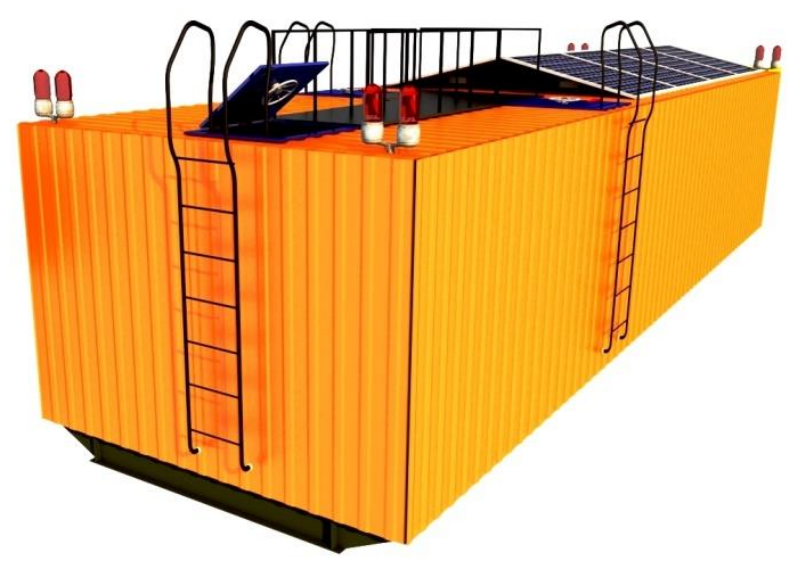

Gambar 19 Perspektif tsunami pods

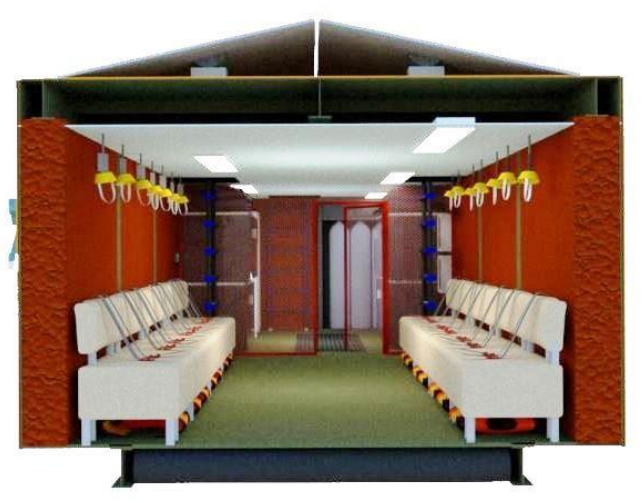

Gambar 20 Potongan melintang interior

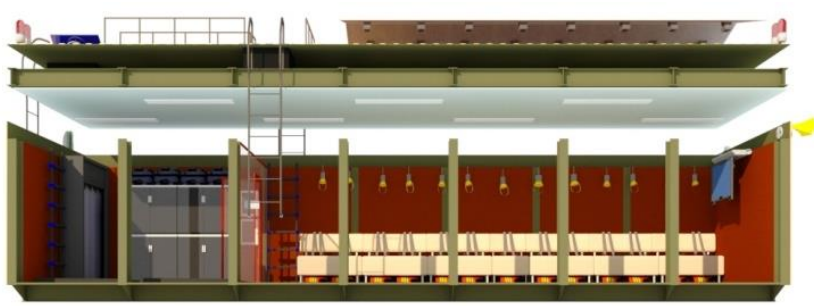

Gambar 21 Potongan memanjang interior

Sistem mekanikal elektrikal tersimpan di dalam plafon dan dinding tsunami pods. Jalur oksigen dari tabung oksigen ke masker oksigen ditiap kursi tersimpan di dalam plafon. Informasi kondisi luar disampaikan melalui monitor yang disediakan di dalam kabin tsunami pods. Suplai oksigen, pencahayaan dan tata udara tersimpan di dalam dinding dan plafon atau di bawah atap pods. Material pelapis dinding dan atap menggunakan material fiber semen yang di dalamnya terdapat sistem elektrikal untuk pencahayaan, komunikasi dan tata udara. Ilustrasi kabin disampaikan pada Gambar 21. 


\section{KESIMPULAN}

Berdasarkan hasil perhitungan dan perencanaan atau rancang bangun tsunami pods sebagai Tempat Evakuasi Sementara (TES), dapat disimpulkan bahwa Tsunami pods didesain menggunakan pelat corrugated (CSP) dengan dimensi exterior pods panjang $11.00 \mathrm{~m}$ lebar $3.025 \mathrm{~m}$ dan tinggi $2.58 \mathrm{~m}$. Dimensi interior panjang $10.63 \mathrm{~m}$, lebar 2.65 $\mathrm{m}$ dan tinggi $2.08 \mathrm{~m}$. Deck lantai menggunakan plat datar $12 \mathrm{~mm}$.

Hasil perhitungan struktur menunjukkan bahwa rangka baja WF 250.125.6.9 sebagai kolom dan balok, UNP 100.50.5 sebagai bracing dan pelat corrugated SS 400 aman digunakan sebagai material konstruksi tsunami pods.

Sistem mekanikal dan elektrikal tersimpan di dalam deck lantai, dinding dan plafon pods. Baterai sebagai power supply disimpan di bawah deck lantai. Suplai oksigen, pencahayaan dan tata udara tersimpan di dalam dinding dan plafon atau di bawah atap pods. Sedangkan dinding dan atap dilapisi dengan material fiber semen yang di dalamnya terdapat sistem elektrikal untuk pencahayaan, komunikasi dan tata udara.

\section{UCAPAN TERIMAKASIH}

Ucapan terima kasih penulis sampaikan kepada Pusat Penelitian dan Pengabdian kepada Masyarakat (P3M) Politeknik Negeri Banyuwangi dan Jurusan Teknik Sipil Politeknik Negeri Banyuwangi atas semua fasilitas dan dukungan yang telah diberikan dalam pelaksanaan kegiatan Penelitian.

\section{DAFTAR PUSTAKA}

[1]. http://balai3.denpasar.bmkg.go.id/tentang-gempa. (1999, Januari 23). Dipetik Oktober 11, 2019, dari http://balai3.denpasar.bmkg.go.id/

[2]. http://p2mb.geografi.upi.edu/. (2010). Dipetik Oktober 4, 2019, dari http://p2mb.geografi.upi.edu/Tsunami.html

[3]. FEMA P-646 tentang Guidlines for Design of Structures for Vertical Evacuation from Tsunamis. (2012). California: Federal Emergency Management Agency.

[4]. http://lipi.go.id/. (2012, Mei 2). Dipetik Oktober 4, 2019, dari http://lipi.go.id/berita/single/IndonesiaMiliki-127-Gunung-Api-Aktif/7448

[5]. SNI 1726 : 2012 tentang Tata Cara Perencanaan Ketahanan Gempa untuk Struktur Bangunan Gedung dan Non Gedung. (2012). Jakarta: BSN Indonesia.

[6]. SNI 1729 : 2015 tentang Spesifikasi untuk Bangunan Gedung Baja Struktural. (2015). Jakarta: BSN Indonesia.
[7]. Ashar, F., \& dkk. (2014). The analysis of tsunami vertical shelter in Padang city. 4th International Conference on Building Resilience (hal. 916-923). Salford Quays: Procedia Economics and Finance.

[8]. Ashar, F., Amaratunga, D., \& Haigh, R. (2014). The analysis of tsunami vertical shelter in Padang city. 4th International Conference on Building Resilience (hal. 916-923). Salford Quays: Procedia Economics and Finance.

[9]. Ernst, \& Neufert, P. (1996). Architects' Data. Jakarta: PT. Penerbit Erlangga.

[10]. Pimanmas, A. \&. (2011). Structural Design Guideline For Tsunami Evacuation Shelter. Journal of Earthquake and Tsunami.

[11]. Rita, E., \& dkk. (2017). Tsunami Shelter in Padang City: Location Suitability and Management Issue. 3rd International Conference on Construction and Building Engineering (ICONBUILD) (hal. 110003-1 110003-6). AIP Publishing.

[12]. Rita, E., Permata, R., Yonne, H., \& Carlo, N. (2017). Tsunami Shelter in Padang City: Location Suitability and Management Issue. 3rd International Conference on Construction and Building Engineering (ICONBUILD) (hal. 110003-1 - 110003-6). AIP Publishing.

[13]. Suharyanto, A., \& dkk. (2012). Predicting Tsunami Inundated Area and Evacuation Road Based On Local Condition Using GIS. Journal of Environmental Science, Toxicology and Food Technology, 5-11.

[14]. Suharyanto, A., Pujiraharjo, A., Usman, F., \& Murakami, K. (2012). Predicting Tsunami Inundated Area and Evacuation Road Based On Local Condition Using GIS. Journal of Environmental Science, Toxicology and Food Technology, 5-11.

[15]. Sun, Y., Yamori, K., Tanisawa, R., \& Kondo, S. (2013). Consciousness of Disaster Risk and Tsunami Evacuation: A Questionnaire Survey in Okitsu, Kochi Prefecture. Journal of Natural Disaster Science, 127141. 